\title{
Research on the economic development impact of earthquake disaster in China
}

\author{
Guoqu Deng ${ }^{*}$, Jianbin $\mathrm{Si}, \mathrm{Li} \mathrm{Li}$, and $H u$ Chen \\ School of Management, Henna University of Science and Technology, Luoyang, China, 471023
}

\begin{abstract}
As one of the areas with frequent earthquake disasters, China's social stability and sustained and healthy economic development have been profoundly affected for a long time. Based on the two-way fixed effect model and a series of deterministic indicators of economic development, including education level, economic development, financial development, fixed asset investment and permanent population, this paper designs a standard regression equation for estimating growth and uses time series panel data to analyze the impact of earthquake disasters on China's economic development. The research results show that the earthquake disaster has an insignificant positive impact on China's GDP. From the point of view of control variables, education level and financial development level have a positive effect on economic development as a whole, but there are certain differences in the degree of influence. The degree of trade openness has a significant impact on GDP, industry and service industries. Moreover, it has a negative impact on agricultural development.
\end{abstract}

Keywords: Earthquake disaster, Economic development, Impact analysis.

\section{Introduction}

China is a country with frequent earthquake disasters, and its social harmony and stability have therefore been greatly challenged. At the same time, earthquake disasters have a certain impact on China's economic development ${ }^{[1-2]}$. In this regard, this paper carries out systematic thinking and analysis. Related important issues are as follows. What impact will the earthquake disaster have on China's economic development? What is the extent of the impact? This paper uses the two-way fixed effect model and estimated growth regression equation to explore the impact of China's earthquake disaster on economic development, thereby providing a reference for decision-making in China's earthquake disaster prevention and relief.

\section{Literature review}

In the context of the steady growth of global disaster losses, research on disaster economics only began in the 1950 s. Since the 1980 s, studies on the economic development impact of

\footnotetext{
* Corresponding author: dengguoqu@,haust.edu.cn
} 
disasters have begun to take into account the socio-economic conditions during the disaster. In foreign research on the impact of disasters on economic development, there are three main areas, which are the research on the impact of specific disasters on regional economic development (Vos et al., 1999; Horwich, 2000; Narayan, 2001; Selcuk and Yeldan, 2001; Benson and Clay, 2004; Halliday, 2006) ${ }^{[3]}$, the research on the impact of disasters on microeconomic development (Paxson, 1992; Townsend, 1994; Udry, 1994) ${ }^{4[]}$, and the research on the impact of disasters on macroeconomic development (Albala-Bertrand, 1993; Tol and Leek, 1999; Skidmore and Toya, 2002; Rasmussen, 2004) ${ }^{[5]}$. Among domestic research, scholars Zhang Xiandong and Shen Rongfang (1995) used the Haroldo-Domar economic growth model to conduct a preliminary estimation of the impact of disaster direct losses on economic growth ${ }^{[6]}$. Lu Cong et al. (2002), Ding Xianjun et al. (2010) and other scholars used the input-output model to derive the ARIO (Adaptive Regiona Iinput Output) model, and analyzed the economic impact of the loss of agricultural output value caused by natural disasters on the entire economic system and the Wenchuan earthquake ${ }^{[7-8]}$. Li Hong et al. (2010) conducted time series modeling and analysis on the socio-economic factors of natural disaster losses to explore the relationship between the evolution of natural disaster losses and the development and changes of economic growth, population, education, and medical care ${ }^{[9]}$.

Earthquake disasters are one of the major disasters in the world. In the domestic and foreign research, theoretical basis includes Cobb-Douglas (Cobb-Douglas) production function and Harlow-Domar economic growth model, and the methods include modified GMM model economic growth model, and fixed research methods such as effects and quantile regression. These studies mainly focus on the economic development impact of a particular earthquake, such as the Los Angeles earthquake, the Kobe earthquake, the Chile earthquake, the Wenchuan earthquake, the Haiti earthquake, and the Great East Japan Earthquake (Kozuhiko and KawashimaS, 1980; Zhang Jifeng, 2011; kidmore and Toya, 2002; Kajitaniy et al., 2013; Lu Jingliang et al., 2014) ${ }^{[10-12]}$. In addition, there are relatively abundant studies on the impact of earthquake disasters in specific regions on economic development (He Daixin et al., 2009; Gu Hongbo et al., 2019 ${ }^{[13-14]}$. The consistency of the research results is that the earthquake will definitely have an impact on economic development, but there are differences in the degree of impact. As for the impact of the earthquake on economic development factors, such as GDP, investment, trade, consumption, education, finance, inflation and employment, the relevance and significance are quite different.

Generally speaking, the current research on the economic development impact of earthquake disasters is still in the exploratory stage. Although the research on the impact of specific earthquakes and earthquake disasters in specific regions on economic development is relatively abundant, the research on the impact of earthquake disasters in a certain country (region) on economic development is still relatively lacking.

Based on China's 2004-2018 earthquake disaster panel data, this paper uses the two-way fixed effect model and estimated growth regression equation to develop the impact of China's earthquake disaster on economic development.

\section{Estimation method}

For endogenous considerations, this paper intends to use the two-way fixed effects model to conduct an empirical analysis of the relationship between earthquakes and China's economic development. The two-way fixed-effects model is to add regional dummy variables and time dummy variables to the model to describe the differences between different provinces that do not change with time and the time differences that do not change with the individual. Simply put, this is to effectively overcome the endogenous problem caused by missing 
variables by adding these two sets of dummy variables to the model. This paper constructs a two-way fixed effects measurement model as follows:

$$
Y_{i t}=\alpha+\beta \times E_{i t}+\gamma \times X_{i t}+\varepsilon_{i}+\mu_{t}+\theta_{i t}
$$

where, the subscript $\boldsymbol{i}$ represents the province (municipalities and autonomous regions), $\boldsymbol{t}$ represents the year, $\boldsymbol{Y}_{i t}$ represents the explained variable that measures the level of regional economic development, $\boldsymbol{E}$ represents the seismic variable, the coefficient $\boldsymbol{\beta}$ represents the impact of the earthquake on economic development, $\boldsymbol{X}_{i t}$ represents the level of the regional economic development, the control variables $\boldsymbol{\varepsilon}_{\boldsymbol{i}}$ and $\boldsymbol{\mu}_{\boldsymbol{t}}$ respectively represent the regional dummy variable and the time dummy variable, and $\boldsymbol{\theta}_{i t}$ represents the random error term.

Table 1. Factors influencing economic development of earthquake disaster.

\begin{tabular}{|c|c|c|c|}
\hline $\begin{array}{c}\text { Influencing } \\
\text { factors }\end{array}$ & Description & $\begin{array}{c}\text { Main evaluation } \\
\text { index }\end{array}$ & Data source \\
\hline $\begin{array}{l}\text { Education } \\
\text { level }\end{array}$ & $\begin{array}{l}\text { Education level is the } \\
\text { comprehensive expression } \\
\text { of the average cultural } \\
\text { depth and the advanced } \\
\text { level of education among } \\
\text { all groups in a country (or } \\
\text { region). }\end{array}$ & $\begin{array}{l}\text { Junior middle school } \\
\text { gross enrollment rate } \\
\text { (the proportion of the } \\
\text { number of junior high } \\
\text { school students in the } \\
\text { total school-age } \\
\text { population) }\end{array}$ & $\begin{array}{l}\text { China Education } \\
\text { Statistics Yearbook, } \\
\text { China Population and } \\
\text { Education Statistics } \\
\text { Yearbook, etc. }\end{array}$ \\
\hline $\begin{array}{l}\text { Economic } \\
\text { development }\end{array}$ & $\begin{array}{l}\text { The level of economic } \\
\text { development will inevitably } \\
\text { have a driving effect on the } \\
\text { economic development of } \\
\text { the region. }\end{array}$ & Economic growth rate & $\begin{array}{l}\text { China Statistical } \\
\text { Yearbook, etc. }\end{array}$ \\
\hline $\begin{array}{c}\text { Financial } \\
\text { development }\end{array}$ & $\begin{array}{l}\text { The combination of the } \\
\text { financial system and } \\
\text { financial policies promotes } \\
\text { economic growth and } \\
\text { rational use of financial } \\
\text { resources to ultimately } \\
\text { achieve sustainable } \\
\text { financial and economic } \\
\text { development. }\end{array}$ & $\begin{array}{l}\text { Financial efficiency } \\
\text { (the ratio of credit to } \\
\text { GDP provided to non- } \\
\text { financial private } \\
\text { companies or the non- } \\
\text { financial private } \\
\text { sector) }\end{array}$ & $\begin{array}{c}\text { China Financial Statistics } \\
\text { Yearbook, etc. }\end{array}$ \\
\hline $\begin{array}{l}\text { Investment } \\
\text { in fixed } \\
\text { assets }\end{array}$ & $\begin{array}{c}\text { Fixed asset investment } \\
\text { provides a guarantee for the } \\
\text { construction of } \\
\text { infrastructure and } \\
\text { earthquake-resistant } \\
\text { systems in various regions. }\end{array}$ & $\begin{array}{l}\text { Proportion of fixed } \\
\text { investment (total } \\
\text { investment in fixed } \\
\text { assets as a percentage } \\
\text { of GDP) }\end{array}$ & $\begin{array}{c}\text { China Statistical } \\
\text { Yearbook, Urban and } \\
\text { Rural Statistical } \\
\text { Yearbook, etc. }\end{array}$ \\
\hline $\begin{array}{l}\text { Permanent } \\
\text { residents }\end{array}$ & $\begin{array}{l}\text { The local permanent } \\
\text { household population } \\
\text { provides human capital for } \\
\text { regional development. }\end{array}$ & $\begin{array}{l}\text { Number of permanent } \\
\text { residents }\end{array}$ & $\begin{array}{c}\text { China Statistical } \\
\text { Yearbook }\end{array}$ \\
\hline
\end{tabular}

\section{Descriptive variables}

The explanatory variable of this paper is China's regional economic development. Based on the availability of data, this paper selects the following four indicators. First, considering the impact of economic development, the gross domestic product (GDP) of each region is selected to measure the level of economic development. Secondly, considering the impact of the earthquake on the economic development of industries such as agriculture, industry and 
service industry, the three indicators of primary industry output value, secondary industry output value and tertiary industry output value are selected. The explanatory variable is earthquake. In this paper, the area and year where no earthquake occurred is set to 0 , and the area where an earthquake occurred in the current year is set to 1 . After fully considering the impact of earthquake magnitude (level) on the economy, this paper also selects the earthquake magnitude as an explanatory variable.

With reference to Li Junjie (2016), Du Hui (2017), Zhang Tao (2018) and other documents ${ }^{[15-17]}$, this study also added a series of indicators that determine economic development as control variables to reduce endogenous impacts, including the economic development level, education level, financial development, fixed asset investment, and local permanent population. The specific description of each indicator is as follows.

\section{Data sources and descriptive statistics}

Based on panel data from China's 31 provinces (municipalities and autonomous regions) from 2004 to 2018, this study assesses the impact of the earthquake on the economic development. The sample data comes from the China Statistical Yearbook, Urban and Rural Statistical Yearbook and local statistical yearbooks over the years. The earthquake data comes from the official website of the China Earthquake Administration. The reason why this article takes samples after 2004 is because the earthquake-related data of previous years are difficult to obtain through official channels. In order to ensure the comparability of the data and the persuasiveness of the empirical results, missing values are eliminated. The final sample size is 6045. The basic descriptive statistics of each variable are shown in Table 2.

Table 2. Variable descriptive statistics.

\begin{tabular}{|c|c|c|c|c|c|}
\hline Variable & $\begin{array}{c}\text { Sample } \\
\text { size }\end{array}$ & $\begin{array}{c}\text { Mean } \\
\text { value }\end{array}$ & $\begin{array}{c}\text { Standard } \\
\text { deviation }\end{array}$ & $\begin{array}{c}\text { Minimum } \\
\text { value }\end{array}$ & $\begin{array}{c}\text { Maximum } \\
\text { value }\end{array}$ \\
\hline Year & 465 & 2011 & 4.325147 & 2004 & 2018 \\
\hline Province & 465 & 16 & 8.953905 & 1 & 31 \\
\hline $\begin{array}{c}\text { Whether there is an } \\
\text { earthquake }\end{array}$ & 465 & .2150538 & .4113021 & 0 & 1 \\
\hline $\begin{array}{c}\text { Earthquake magnitude } \\
\text { Gross domestic product }\end{array}$ & 465 & .4064516 & 1.03201 & 0 & 8 \\
\hline $\begin{array}{c}\text { Primary industry output } \\
\text { value }\end{array}$ & 465 & 1441.773 & 1169.553 & 44.3 & 4979.08 \\
\hline $\begin{array}{c}\text { Secondary industry } \\
\text { output value }\end{array}$ & 465 & 7625.39 & 7564.006 & 52.74 & 42129.37 \\
\hline $\begin{array}{c}\text { Tertiary industry output } \\
\text { value }\end{array}$ & 465 & 7483.735 & 8154.751 & 123.3 & 54710.37 \\
\hline Economic development & 465 & .1375796 & .0764502 & -.2796 & .32274 \\
\hline $\begin{array}{c}\text { Investment in fixed } \\
\text { assets }\end{array}$ & 465 & 9736.517 & 10038.21 & 133.96 & 55202.72 \\
\hline Permanent residents & 465 & 4320.335 & 2732.396 & 276 & 11346 \\
\hline $\begin{array}{c}\text { Education level } \\
\text { Financial development } \\
\text { level }\end{array}$ & 465 & .0514577 & .0222064 & .024774 & .187008 \\
\hline
\end{tabular}




\section{Analysis of estimation results}

The above variable data is substituted into the formula (1), and the panel data regression analysis is performed by stata15.0 software. Corresponding inspections are performed on the obtained data, and all the results in Table 3 are obtained.

Table 3. Regression Analysis Results of China's Earthquake Disasters and Economic Development.

\begin{tabular}{|c|c|c|c|c|}
\hline \multirow[b]{2}{*}{ Variable: } & \multicolumn{4}{|c|}{ Dependent variable: } \\
\hline & $\begin{array}{l}\text { GDP } \\
\text { growth }\end{array}$ & $\begin{array}{c}\text { Primary } \\
\text { industry } \\
\text { growth }\end{array}$ & $\begin{array}{r}\text { Seco } \\
\text { industr }\end{array}$ & $\begin{array}{c}\text { Tertiary } \\
\text { industry } \\
\text { growth }\end{array}$ \\
\hline \multirow{2}{*}{ Earthquake } & -0.007 & -0.008 & $1.031 * * *$ & -0.002 \\
\hline & $(-0.421)$ & $(0.904)$ & $(1.835)$ & $\{-0.327\}$ \\
\hline \multirow{2}{*}{ Earthquake level } & -0.012 & $-0.072 * *$ & $0.093 * *$ & -0.023 \\
\hline & $\{-0.521\}$ & $\{-3.103\}$ & $(1.825)$ & {$[-0.245]$} \\
\hline \multicolumn{5}{|l|}{ Control variables: } \\
\hline \multirow{2}{*}{ Education level } & 0.185 & $1.812^{* * *}$ & 0.351 & $2.699 * * *$ \\
\hline & $(0.408)$ & (3.093) & $(0.215)$ & $(4.143)$ \\
\hline \multirow{2}{*}{ Economic development } & $1.203 * *$ & $2.042 * * *$ & $1.182 * * *$ & $1.791 * * *$ \\
\hline & $(2.508)$ & {$[2.184]$} & $(2.247)$ & (3.176) \\
\hline \multirow{2}{*}{$\begin{array}{c}\text { Financial development } \\
\text { level }\end{array}$} & $0.5012 * * *$ & -0.284 & $0.687 *$ & 0.196 \\
\hline & $(1.528)$ & $(-0.642)$ & (1.695) & $(1.538)$ \\
\hline \multirow{2}{*}{$\begin{array}{l}\text { Investment in fixed } \\
\text { assets }\end{array}$} & $-3.857 * * *$ & $-1.085^{*}$ & $-5.057 * * *$ & $-4.071 * * *$ \\
\hline & $(-6.438)$ & (-1.709) & $(-5.624)$ & $\{-6.191)$ \\
\hline \multirow{2}{*}{ Permanent residents } & $-5.926^{* * *}$ & $-3.523 * * *$ & $-5.065^{* * *}$ & $-3.842 * * *$ \\
\hline & $(-4.914)$ & $(-4.841)$ & $(-2.905)$ & {$[-3.057)$} \\
\hline AR (2) test (p value) & 0.204 & 0.151 & 0.538 & 0.391 \\
\hline Hansen test ( $\mathrm{p}$ value) & 0.501 & 0.303 & 0.299 & 0.385 \\
\hline
\end{tabular}

Note: $\operatorname{In}($ is the $\mathrm{t}$ value. *,**,*** represent the significance level of $10 \%, 5 \%$, and $1 \%$ respectively. The null hypothesis of $\mathrm{AR}(2)$ test is that the error term after the difference does not exist in the second-order sequence correlation. The null hypothesis of Hanse test is that the instrumental variables are not correlated with the error term.

In general, China's earthquake disaster has no significant impact on GDP, indicating that although China's earthquake disaster has suffered serious losses, its impact on economic development is not significant. The earthquake has a negative impact on GDP, agriculture and service industries $(-0.007,-0.008$ and -0.002 , respectively), but a significant positive impact on industrial development (1.031). On the one hand, earthquakes will destroy agricultural infrastructure and farmland, which will have a negative impact on agricultural output. On the other hand, earthquakes may change the structure of the economic market and have a positive impact on industries and other industries. The earthquake will not only severely affect labor and capital and damage buildings, infrastructure and factories, but also cause a significant reduction in the ratio of capital to labor and an increase in investment capital, average output, and marginal products. Furthermore, if a capital is destroyed and then replaced with a better quality capital, factor productivity will increase, which will further promote economic growth.

From the point of view of control variables, education level and financial development level have a positive effect on economic development overall, but there are certain differences in the degree of influence. The level of education has little effect on GDP and 
industry, but has a significant impact on agriculture and service industries. the level of financial development has a significant impact on GDP, an impact on industrial development, as well as little impact on the development of the service industry. In addition, it has a negative impact on agricultural development. This is because the more developed the financial industry, the more serious the "marginalization" of the rural financial market, which will lead to a large amount of funds flowing to other industries and thus affect agricultural development. Trade openness has a significant impact on GDP, industry and service industries, but has a negative impact on agricultural development. This shows that China's agriculture is still in the development stage, which is a typical weak industry compared with foreign developed countries. The higher the degree of trade openness, the greater its negative impact on agricultural development.

\section{References}

1. Albala-Bertrand, J. M.. Political Economy of Large Natural Disasters. Oxford: Clarendon Press ( 1993)

2. Christiaensen, L. K., \& Subbarao. Towards an Understanding of Household Vulnerability in Rural Kenya. Journal of African Economies.14,4(2005)

3. Ding, X. J., Yang, C. H., \& Zhu, K. F. Disaster economic impact evaluation method based on input-output model. Journal of Natural Disasters. 19,2 (2001)

4. Du, H. (2017). Does the migration of rural population change China's agricultural output? [J]. Jiangxi Social Sciences. 37(9): 84-92.

5. FEMA (Federal Emergency Management Agency). HAZUS 99 Estimated Annualized Losses for the United States. Washington: Federal Emergency Management Agency(2001)

6. Gu, H. B., \& Li, C. M.. Research on the impact of earthquakes on regional agricultural economy: Empirical analysis based on panel data of prefecture-level cities in western China. Journal of Yunnan Agricultural University (Social Sciences). 13,1 (2019)

7. He, D. X., Ye, Z. R., \& Jiang, X. L. The impact of earthquakes and economic environment changes on economic development: The latest proof from Sichuan, Economic Management. 5 (2009)

8. Li, H.. Analysis of the impact of social and economic factors of natural disasters. China Population·Resources and Environment. 20,11 (2010)

9. Li, J. J., Li J. P., Niu Y. X., \& Zhang, C. X. Evaluation of the economic effects of comprehensive agricultural development investment growth: Empirical analysis based on the panel data model of each province. Agricultural Technology and Economy. 11 (2016)

10. Lu, C., Wei Y. M., \& Fan, Y. Quantitative analysis model of the impact of disasters on the national economy and its application. Journal of Natural Disasters. 11,3 (2002)

11. Lu, J. L., Feng, S. Z., \& Ai, C. R. The impact of natural disasters and government assistance on farmers' income and consumption: Experience from the Wenchuan earthquake. Economics (Quarterly). 13,2 (2014)

12. Rasmussen, T. N. Macroeconomic implications of natural disasters in the Caribbean. IMF working paper (2004)

13. Skidmore, M., Toya, H. Economic development and the impacts of natural disasters. Economic Letters. 4 (2007) 
14. Xie, W., Li, N., \& Hu, A. J. Economic Impact Assessment of Environmental Disasters Based on CGE Model: Taking Hunan Snow Disaster as an Ex-ample. China Population·Resources and Environment. 22,11 (2012).

15. Zhang, J. F. The impact of the Great East Japan Earthquake on the Japanese economy and the world economy. Journal of the Graduate School of the Chinese Academy of Social Sciences. 7 (2011)

16. Zhang, X. D., \& Shen, R. F.. Quantitative analysis of the relationship between disasters and economic growth. Journal of Natural Disasters. 4,4(1995)

17. Zhang, T. Policy intervention and China's agricultural growth: 1988-2013. Economic Research of Nankai University. 5 (2018) 